\title{
Field Principles for Countering and Displacing Extremist Narratives
}

\section{by Alejandro Beutel, Stevan M Weine, Aliya Saeed, Aida Spahic Mihajlovic, Andrew Stone, John Oakley Beahrs, Stephen B Shanfield}

\section{$(\mathrm{cc}) \mathrm{EY}$}

This work is licensed under a Creative Commons Attribution 3.0 License.

\section{Abstract}

U.S. policymakers regard countering and displacing extremist narratives to be a core strategy of countering violent extremism. The rise of the Islamic State of Iraq and Syria (ISIS), which uses highly sophisticated messaging to reach U.S. young persons, has further emphasized the need for this strategy. However, to date there has been little discussion of field principles to guide community-based practitioners in either countering or displacing extremist narratives associated with violent Islamist extremism. Drawing upon existing theory, empirical evidence, and practical experience from across multiple disciplines, this article seeks to fill these gaps with a set of field principles to guide both developing the content of new counter-narratives and alternative narratives and then delivering the new counter-narratives and alternative narratives.

Keywords: Countering violent extremism; terrorism; ISIS; Al-Qaeda; narratives

\section{Introduction}

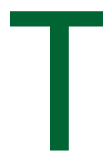

errorism researchers and counter-terrorism practitioners have for some time recognized the power of narratives to recruit individuals into violent extremist activities (Schmid, 2014). This recognition has been incorporated into the new field of countering violent extremism (CVE). CVE includes an array of policies, programs, and initiatives designed to prevent violent ideologies from taking hold of people in the first place, and to stop them from crossing the line towards actual violence (Nasser-Eddine, et al., 2011). At the February 2015 White House Summit on Countering Violent Extremism, countering and displacing extremist narratives was one of the top priorities. "Countering" means offering narratives that directly challenge the extremist message and "displacing" means offering alternative narratives.

The effort to develop new strategies has become more urgent in the age of ISIS, which employs highly sophisticated and effective communication strategies. Jessica Stern and J.M. Berger (2014) describe how ISIS' messaging and savvy use of social media platforms have upended traditional jihadi methods of recruitment, resulting in thousands of fighters and other volunteers being recruited to their cause.

New counter-messaging initiatives have been developed, such as the Peer to Peer Challenging Extremism Initiative, a public-private partnership between the State Department and EdVenture Partners, which helps college students develop social or digital campaigns to counter violent extremism (Glavin, 2015). Such initiatives should be applauded, but also underline the need for empirical or best practices guidelines to help inform their efforts.

In this paper we seek to contribute to the efforts to counter and displace the violent narratives that violent Islamist extremists use to target and persuade American Muslims to radicalize into violence. This article focuses on responding to these narratives due to the particularly deadly nature of violent Islamist extremist 


\section{Journal of Terrorism Research}

movements (Piazza 2009) and the high priority assigned to them by U.S. national security policymakers (Johnson 2014; Comey 2014). Engaging in a broader analysis inclusive of other actors such as the U.S. (Perliger 2012; Furlow 2012) and European (Kundnani 2012; Dafnos 2014) violent Far Right is beyond the scope of this article. Nonetheless, consistent with current counter-narratives scholarship (e.g. Braddock and Horgan 2015) and practice (e.g. Tuck and Silverman 2016) we assume the field principles articulated in this article are also applicable to other violent movements, such as the U.S. violent far right and U.S. violent far left. While informed by several of the authors' direct experiences with American Muslim communities, we also draw upon a broad diversity of literature in terrorism studies and other disciplines that is ideologically neutral in its content and scope.

This article draws from the scholarly literature in terrorism studies, communications, and public health, as well as other publications that incorporate and highlight community-sourced perspectives on narrative development and messaging. It also draws upon our own direct engagement with U.S. Muslim communities, including community-participatory research (Weine), community leadership (Saeed), and community-based civic and political advocacy (Beutel).

With some notable exceptions, (Ramsay 2012; Braddock 2012; Braddock 2015; Braddock and Dillard, forthcoming) there is a general deficit of empirical evidence on the effectiveness of counter-narratives and how countering extremist narratives and messaging elicits desired outcomes. Braddock and Horgan (2015) offered communication and psychology theory-based procedures for (1) analyzing terrorist narratives, (2) constructing counter-narratives that challenge terrorist narratives, and (3) disseminating the counternarratives to overcome barriers to persuasion. For example, they found that developing effective messaging should, "Incorporate themes that advocate an alternative view of the terrorist narrative's target" (Braddock and Horgan 2015,9) This strategy is consistent with prior claims from policymakers (Grant 2015) and researcher-practitioners (Matejic 2015) that counter-narratives have limited utility and that violent narratives must ultimately be replaced, not just countered.

One observer noted that CVE policies, "to date have been guided largely by intuition and anecdotal observation, rather than by clearly relevant metrics." (Berger and Strathern 2013,37) We believe that this includes the development and delivery of narrative content. Some ways to evaluate alternative and counternarratives include social network analysis, (Hedayah and International Center for Counter-Terrorism 2014, 4) polling, focus groups, sentiment analysis, (McCants and Watts 2012,2) and other innovative scoring systems to measure influence and exposure over social media platforms like Twitter (Berger and Strathearn 2013). The findings of these evaluations can begin to build an evidence-based set of lessons learned that can inform future efforts.

The article is divided into four sections. First, we define key terms and concepts, such as "narrative," "counternarrative," and "alternative narrative." Second, we suggest field principles for developing the content of new counter-narratives and alternative narratives. Third, we offer field principles for delivering new content. Both sets of field principles are offered with a conscious, but not exclusive focus on U.S. Muslim community actors. Fourth, we discuss the implications for research, practice, and policy. 


\section{Journal of Terrorism Research}

\section{Key Terms and Concepts}

\section{Narrative}

In the context of violent extremism, drawing from Scott Ruston (2009), we define an extremist narrative as a system of stories that hang together to provide a coherent view of the world for the purpose of supporting individuals, groups, or movements to further illegal violent and violence-assisting activities.

Researchers have identified 13 "master" narratives that violent Islamist extremist movements, such as AlQa'ida, use to influence their audiences. These narratives utilize historical events or religious concepts, such as the abolishing of the Caliphate in 1924 or Qur'anic passages on Satan (Arabic translation Shaytan), to influence their audience (Halverson, Goodall, and Corman 2011).

Each of these "master" narratives has 3 common elements:

- An underlying grievance in which a non-Muslim "other", typically Westerners, Zionists, and "Crusaders" are responsible, in collaboration with local dictators, for the mistreatment and humiliation of Muslims around the world.

- The notion of an ideal society where an Islamic state or the "Caliphate" rules under a purist notion of "sharia," or perfect Divine law (which in reality is conflated with archaic interpretations of fiqh, the imperfect human effort to interpret Divine law) (Quraishi-Landes 2013, 10). The establishment of a "sharia" governed polity serves to replace the corrupt governance structures of secular Westernbacked regimes.

- A means of moving from that grievance to achieving an ideal society namely through violent activity advocated by AQ and the ISIS (Schmid 2014, 6).

While messages from AQ and ISIS share various aspects and degrees of emphasis of these three elements, their narratives also diverge substantially. The differences between the two movements center on: 1) their ultimate political goals, and;2) their relationship to violence. Both movements share an interest in establishing a Caliphate. For AQ, this is mostly a theoretical ideal. For ISIS, this is an active engagement in state building and governance. As a result, AQ's recruitment narratives and members are a "vanguard" movement, reflecting a more selective and elitist mentality. By contrast, ISIS is much more open to recruiting a broader array of people from various backgrounds and skill sets to fulfill diverse governance roles including doctors, engineers, nurses, elder caretakers, etc. As a result, each movement's use of violence also diverges substantially. For AQ, violence is a means to a political end (i.e. withdrawal of Western support from local Muslim regimes.) For ISIS violence is an end in of itself - a sign of its commitment to creating a "pure" Muslim society and polity. As a result, ISIS appears to be far more promiscuous and comfortable with its use of wanton violence against non-combatants, which is also reflected in its online messages to recruit (Fink and Sugg 2015; Al-Tamimi 2014).

By employing religiously-laden motifs, AQ and ISIS' narratives exploit two basic human psychological needs: 1) cognitive closure which, "amounts to the quest for certainty, and eschewal of ambiguity... It is the quest for structure and coherence in one's outlook and beliefs" (Kruglanski 2014) and; 2) a quest for significance, which, "denotes the supreme importance to humans of being noticed, mattering, and deserving honor and esteem." (Ibid.) Earning the status of a "hero" and a "martyr" plays on this quest.

There are several different ways that narratives can displace or counter extremist narratives. The Institute 


\section{Journal of Terrorism Research}

for Strategic Dialogue (ISD) has described a "messaging spectrum" that include three types of messaging activities: 1) government strategic communications; 2) counter-narratives; and 3) alternative narratives. (Briggs and Feve 2013) In a U.S. domestic context, legal and strategic considerations, which are discussed later in this article, proscribe U.S. government actors from engaging in any counter-ideological strategic context. (Rascoff, 2012) Therefore, we mainly focus on counter-narratives and alternative narratives, which are elaborated upon in the next section.

\section{Counter-Narrative and Alternative Narrative}

We define a counter-narrative as a system of stories that hang together to provide a coherent view of the world for the explicit purposes of combating violent extremist narratives, and eliciting legal and non-violent activities in support of individuals, groups, or movements, which support that worldview. Counter-narratives seek to directly address a violent narrative after it has been delivered to an intended audience, making them a reactive type of messaging. For instance, videos that respond to the religious justifications of violent extremists (Muslim Public Affairs Council 2010) are part of a broader counter-narrative that sees groups like $\mathrm{AQ}$ and ISIS as religiously inauthentic.

An alternative narrative is a system of stories that hang together to provide a coherent view of the world to promote and elicit legal and non-violent activities in support of individuals, groups, or movements, which support that worldview. Unlike counter-narratives, alternative-narratives are not explicitly intended to directly confront violent narratives, although they may have secondary outcomes, which do displace them. Moreover, because they do not necessarily seek to directly address violent narratives, counter-narratives are not reactive per se; these narratives can proactively lead to anti-violence outcomes. For instance, an alternative narrative that promotes a faith-based form of citizen involvement and civic engagement among youth may be primarily intended to increase voter registration and participation rates among 18-year olds. However, these narratives can have a secondary effect of intellectually grounding individuals against violent narratives that say a person cannot be a loyal American citizen and an observant Muslim at the same time.

These different messaging activities are summarized in the table below.

\begin{tabular}{|c|c|c|c|}
\hline What & Why & How & Who \\
\hline $\begin{array}{l}\text { Gov't Strategic } \\
\text { Communications }\end{array}$ & $\begin{array}{l}\text { Action to get the } \\
\text { message out about } \\
\text { what government is } \\
\text { doing, including public } \\
\text { awareness activities }\end{array}$ & $\begin{array}{l}\text { Raise awareness, forge } \\
\text { relationships with key } \\
\text { constituencies and } \\
\text { audiences and correct } \\
\text { misinformation }\end{array}$ & Government \\
\hline Counter-Narratives & $\begin{array}{l}\text { Directly deconstruct, } \\
\text { discredit and demystify } \\
\text { violent extremist } \\
\text { messaging }\end{array}$ & $\begin{array}{l}\text { Challenge through } \\
\text { ideology, logic, fact or } \\
\text { humor }\end{array}$ & Civil Society \\
\hline $\begin{array}{l}\text { Alternative } \\
\text { Narratives }\end{array}$ & $\begin{array}{l}\text { Undercut violent } \\
\text { extremist narratives by } \\
\text { focusing on what we are } \\
\text { 'for' rather than 'against' }\end{array}$ & $\begin{array}{l}\text { Positive story about social } \\
\text { values, tolerance, openness, } \\
\text { freedom and democracy }\end{array}$ & $\begin{array}{l}\text { Civil Society or } \\
\text { Government }\end{array}$ \\
\hline
\end{tabular}

In discussing countering extremist narratives, the "counter-narrative" is typically mentioned far more 
frequently than other types of messaging activities. Sometimes the other types of messaging activities are misidentified or misunderstood as counter-narratives.

One recent example of a counter-narrative was produced by Ambassador Alberto Fernandez of the U.S. State Department, called "Think Again, Turn Away". Fernandez who wrote the episode himself said that it was inspired by the Terry Jones television series about the Crusades and is a, "riff on jihadist videos describing what a joy ride it is to join ISIL." (Fernandez 2014b) According to Fernandez the goals were three fold: 1) contest the space; 2) redirect the conversation, and; 3) unnerve the adversary (Fernandez 2014a). This video generated lots of controversy in the U.S. (Watts 2015). In our opinion, it seems to go against many common sense principles of what should be done to construct narrative-based strategies and led us to articulate those principles that they might guide persons or organizations working on countering and displacing violent narratives.

\section{Field Principles for Countering Extremist Narratives}

We formulated field principles to inform the practice of countering and displacing extremist narratives, which are summarized in the table below.

\begin{tabular}{|l|}
\hline $\begin{array}{l}\text { Table 2: Suggested Field Principles for Countering and } \\
\text { Displacing Extremist Narratives }\end{array}$ \\
\hline Developing New Narrative Content \\
\hline Utilize Emotional Communication \\
\hline Complicate the Violent Narrative \\
\hline Reframe Rather Than Confront \\
\hline Avoid Fear-Based Messaging \\
\hline Humanize the Subjects \\
\hline Promote Positive Identities \\
\hline Protect Communities' Rights and Liberties \\
\hline Engage Beyond Violent Extremism \\
\hline Delivering New Narratives \\
\hline Know the Intended Audiences \\
\hline Define the Desired Outcomes \\
\hline Choose the Medium(s) of Communication \\
\hline Choose Credible Messengers \\
\hline Do No Harm \\
\hline Diminish the 'Say-Do' Gap \\
\hline Evaluate the Process and Impact \\
\hline
\end{tabular}

\section{Generating New Narrative Content}

Eight field principles were formulated to inform the development of new narrative content.

Utilize emotional communication. Use narratives with powerful emotional content in order to counter the highly emotional messaging of ISIS, as well as other violent extremist organizations. Narratives that are too much rooted in ideas risk losing the attention span of the audiences. Emotional messages that generate moral 


\section{Journal of Terrorism Research}

outrage are regarded as the most effective in pulling individuals into a pathway toward terrorist violence (Bartlett, Birdwell, and King 2010, 98-99; Sageman 2004). Interestingly and in contrast, they also generate moral outrage among wider publics to delegitimize extremist ideology and violence. For example, when violent extremists in Egypt unintentionally killed a 12-year-old girl, Shayma, the Egyptian government widely publicized her death. The death of the young girl generated moral outrage among Egyptians and as a result public sympathy towards the terrorists quickly evaporated. In turn, this fostered to internal demoralization among militants that eventually led to defections and ultimately a cessation of violence (Brachman and McCants 2006).

Complicate the violent narrative. If violent narratives seek to provide certainty and simplicity out of chaos, then one response is to "disrupt" a black-and-white view and provide a more nuanced view. Such counternarratives should, wherever possible, incorporate efforts to promote integrative complexity, or the ability of an individual to see the world and competing values in a nuanced, rather than a binary, manner. Prior research suggests that lowered integrative complexity substantially raises the probability of engaging in violence (Smith, et al. 2008). Programs promoting increased integrative complexity, such as "Being Muslim, Being British," appear to lead to positive anti-violence outcomes (Savage 2011; Savage, Liht, and Williams 2011; Liht and Savage 2013).

Reframe rather than confront. Create narratives that acknowledge the concerns that underwrite much of the sympathy toward extremist groups without validating the violent means that extremists advocate. This employs the same psychological mechanisms that violent extremists use to recruit people-a quest for significance and the need for closure-but uses them for different means. In this way the narrative redirects energies built up by unaddressed grievances, rather than getting involved in a direct ideological confrontation. For instance, a YouTube video by an anti-extremist activist called "Five Considerations for a Muslim on Syria" takes the concerns of its potential audience very seriously. To some extent, the video validates those concerns and grievances, while admonishing those who may seek to solve those grievances using violent means (Abdullah X 2014).

Avoid fear based messaging. Narratives should avoid frightening people into action, given the evidence that such strategies have been ineffective and counterproductive in various fields, including public health (Prevention First 2008; Peters, Ruiter, and Kok 2013) and criminal justice (Petrosino, Petrosino, and Buehler 2004). This does not completely undermine the value of strong emotional appeals or what some call shock value. For example, government agencies, such as the National Counterterrorism Center (NCTC), have employed a modest use of shock value to raise awareness about violent extremist recruitment targeted toward U.S. Muslim communities.

Humanize the subjects. Highlighting the human costs of terrorism can be a powerful reality check to the glossy and sanitized propaganda produced by violent extremists. For instance, the killing of innocent Muslim civilians and harsh realities of constantly being on the run are two of the most powerful reasons why violent extremists decided to "dropout" of their violent lifestyle (Jacobson 2010). Highlighting these aspects of terrorist activities can be a powerful counter-narrative. At the same, while invoking moral outrage at the terrorists, it is important to not necessarily demonize individuals who may be sympathetic to the grievances they articulate. Such efforts can intensify the risk of pushing at-risk individuals further along a pathway toward violent action (Bartlett, Birdwell, and King 2010). Research on disengagement and exiting from terrorism suggests that demonstrating respect and empathy toward target audiences is much more likely to elicit favorable outcomes (Bhulai, Fink, Ziegler 2014; Holmer 2014). 


\section{Journal of Terrorism Research}

Promote positive identities. Alternative narratives seek to supplant the "solutions" that extremist narratives offer to Muslim communities' problems. Moreover, they often appeal to the same type of hero lionizing and psychological levers that AQ and ISIS use in their messaging such as by drawing on traditional Islamic religious concepts and local cultural hero mythologies. In the Middle East, Naif Al-Mutawa created the comic series, "The 99", a group of Muslim superheroes whose group name is taken from the "99 attributes" of God mentioned in the Qur'an (Merica 2011; Truitt 2011; The99Kids.com n.d.). In the United States, Marvel Comic's new "Ms. Marvel" character is a 16-year old Pakistani-American teenager named Kamala Khan who is the creation of G. Willow Wilson, a Muslim convert and comic writer (Hudson 2014).

Protect communities' rights and liberties. Narratives should aim to strengthen the defense of civil rights and civil liberties of communities. For example they can reframe or subsume the issue from one that is about "countering violent extremism" to "preventing targeted violence" (we discuss this more in the next section). Moving away from frames of "terrorism" and "violent extremism"-which often trigger a false association with Islam-reduces security-driven anxieties of the general population toward Muslims that in term fuels anti-Muslim animus (Das et al., 2009; Khan and Ecklund 2012; Sides and Gross 2013). This can also have the benefit of weakening violent narratives that claim government efforts to counter violent extremism are part of a so-called "War Against Islam” (al-Awlaqi 2008a; al-Awlaqi 2008a; Khan 2011, 3, 9)

Engage beyond violent extremism. Narratives should engage other types of violent extremism, specifically seeking to recruit Muslims into violent action. Indeed, a major criticism has been that, "violent extremism is a phenomenon that is not unique to American Muslim communities, [but] the government's CVE program remains focused solely on American Muslim communities" (Council on American Islamic RelationsCalifornia 2014). One alternative example is National Outreach for Hate Awareness and Threat Education (NO HATE) USA, a student-led violent prevention awareness campaign. NO HATE USA's philosophy is to fold CVE into a broader focus of preventing targeted violence (2015). This approach appears to have at least two benefits. First, it avoids being limited by geographic trends of violent extremism in the United States, which tend to cluster in 10 counties (LaFree and Bersani 2012). By contrast, acts of targeted violence, such as mass shooters, appear to occur throughout the United States without any particular geographic clustering (Blair and Schweit 2013). In addition, framing the issue as targeted violence serves to broaden public safety relationships with U.S. Muslim communities beyond a narrow focus on counter-terrorism intelligence gathering. Instead it is based on broader public safety concerns that affect all Americans. Rather than being seen as singled out, U.S. Muslims, in partnership with other communities have a narrative around which they can be comfortably united with their fellow citizens to promote the public good by actively working to enhance public safety.

\section{Delivering New Narratives}

Another seven field principles were identified to inform the delivery of new narratives.

Know the intended audiences. Choosing a specific group or groups of persons who you want to reach and learn all you can about them. For example, this could be an entire diaspora community, or late adolescents and young adults in that community, or their parents or teachers. It could also be the extremists themselves. Being clear about which one is of crucial importance to successful delivery and reception.

Define the desired outcomes. Clarify what kind of changes you want to impact. This could include changing knowledge, attitudes, and/or behaviors. For example, they may have an aim of specifically undermining the credibility of violent extremist leaders or organizations, or seeking to empower peers and parents to challenge 


\section{Journal of Terrorism Research}

young persons who may want to become foreign fighters.

Choose the medium(s) of communication. Select the most appropriate medium for reaching your intended audience. For instance, adolescent and young adult audiences could be potentially be best reached via social media platforms like Facebook and Twitter. Whereas a public service announcement aired on a television or radio channel may be better for reaching a whole community.

Choose credible messengers. Narratives should be spoken by trusted and legitimate sources. In the U.S., due to legal and strategic considerations this means that the primary messengers of alternative and counternarratives are, and should be, private American Muslim individuals and non-governmental civil society actors (Rascoff 2012). In the United States, the main legal issue related to counter-messaging efforts has to do with the First Amendment of the U.S. Constitution, which prohibits government endorsement of any religious tradition over another in public life. This includes prohibiting the use of taxpayer funds to promote certain interpretations of any religion that advocate non-violence over religious iinterpretations that do not. In strategic terms, U.S. government security agencies lack trust and credibility among American Muslim communities, due to negative perceptions related to domestic surveillance policies. (Ibid.) Choosing credible voices may include former extremists and militants because they may have ongoing social relationships with individuals who remain involved in hateful and violent movements (Braddock and Horgan 2015). Beyond that, other contextual considerations should be weighed. Victims of attacks or former violent extremists may be some of the most effective messengers because they speak with the unique moral authority of the survivor or witness (Jacobson 2010).

Do no harm. Narratives that have the potential to make a difference can also do harm. For example, humor and ridicule in anti-extremism messaging can be a double-edged sword. One study on satire of terrorist acts noted, "Just as an off color joke can offend your co-workers or sour a personal relationship, humor has the potential to be divisive and motivating in ways that are detrimental to larger policy goals" (Goodall et al. 2012). Knowing the target of the ridicule, and the intent of the ridicule is important. If the target is a particular terrorist leader, with the intent of making him/her look bad and have potential recruits no longer see him/her as glamorous, then this increases the probability of success. However if the direct target of ridicule is potential recruits, psycho-social literature would suggest that this will be counter-productive, eliciting a defiance response, instead of compliance (Infante et al. 1992; Infante and Wrigley 1986; Moscovici and Zavalloni 1969; Semic and Canary 1997). This is likely due to ridicule being perceived as an insult by making fun of a person's desire to contribute to a good cause (such as "helping the people of Syria"), albeit in a misguidedly violent way. By contrast, online counter-narrative content such as Abdullah X's "Five Considerations for a Muslim on Syria" uses rhetoric and a communication tone that takes the concerns of its potential audience very seriously (Abdullah X 2014).

Diminish the gap between government policies and rhetoric. Narratives should not be disconnected from realities or available actions for the intended audiences. For example, narratives that promote greater investment in the local community should be accompanied by public-private partnerships that actually create opportunities for that kind of involvement (Ahmed and Ezzedine 2009).

Evaluate the process and impact. Given the lack of evidence regarding the effectiveness of counternarratives, it is vitally important to apply program evaluation methods that evaluate both what impact a message has and how and why it is having that kind of impact. Both qualitative and quantitative approaches to evaluation should be utilized, including polls, focus groups, sentiment tracking, (McCants and Watts 2012) and social media influence metrics (Berger and Strathearn 2013). 


\section{Implications for Policy, Practice, and Research}

Drawing upon a growing body of theory, empirical evidence, and practical experience from across multiple disciplines, we suggested field principles to guide both developing the content of new narratives and delivering new narratives. These principles are not a panacea and are likely to evolve in response to new threats, contexts, and lessons learned. But for the time being, these principles can assist policymakers and practitioners in developing and delivering narratives to counter and displace extremist narratives. Federal, state, and local government officials can let these guidelines inform their recommended best practices, which they encourage community-based practitioners to follow.

Presently, there is near total lack of empirical research on efforts to counter and displace extremist narratives. New efforts that are developed to counter and displace extremist narratives should have a monitoring and evaluation component. Additional new research is needed to support these efforts, especially in two areas.

One research priority area is to develop research that informs community-based practitioners about the narratives used by extremists to recruit individuals into violent action. Muslim community members have expressed concerns about engaging individuals online or in person who are supportive of violent extremists because they fear becoming the subject of a law enforcement investigation. Mainstream Muslims who might otherwise be interested in countering extremist recruitment find themselves at a disadvantage stemming from a lack of knowledge about messaging activities and narratives because they are hesitant to immerse themselves in the environments where such recruitment takes place (Beutel 2013). (A corollary policy implication of this finding is to examine whether or not surveillance practices and the legal standards regulating them are counterproductive, and if so, to reform them.) (Ibid.). One example of addressing this need is an open-source online library of narratives, counter-narratives, and alternative narratives being developed by the University of Maryland's START center (Braniff, 2015). In addition to providing information on extremist narratives and mainstream Muslim counter- and alternative narratives, being housed at a university research center, the library also provides a more comfortable (academic) venue, where community members can learn about this issue.

A second research priority area is to empirically test the process and impact of countering and displacing extremist narratives. Narrative approaches could be applied to analyze the content of narratives developed as well as the response of receivers to those narratives. Community-based participatory research approaches could investigate the community processes involved in the development and delivery of potentially effective narratives. Survey research approaches could be used to measure the impact of the narratives on the target population, for example assessing changes in knowledge, attitudes, and behaviors.

\section{About the authors}

Alejandro J. Beutel is Researcher for Countering Violent Extremism at the National Consortium for the Study of Terrorism and Responses to Terrorism (START). Prior to START, Beutel was the Policy and Research Engagement Fellow at the Institute for Social Policy and Understanding (ISPU), an applied research thinktank specializing in the study and promotion of evidence-based development strategies for positive civic, social, and political engagement outcomes for American Muslim communities. He was also an independent research consultant to several non-profits, private corporations, and think-tanks.

Stevan Weine is Professor of Psychiatry at the University of Illinois at Chicago College of Medicine, where he is also the Director of the International Center on Responses to Catastrophes and the Director of Global Health 


\section{Journal of Terrorism Research}

Research Training at the Center for Global Health. Weine is author of When History is a Nightmare: Lives and Memories of Ethnic Cleansing in Bosnia-Herzegovina (Rutgers, 1999) and Testimony and Catastrophe: Narrating the Traumas of Political Violence (Northwestern, 2006).

Aliya Saeed is a clinical psychiatrist and is actively engaged in her Muslim community including in leadership positions.

Aida Mihajlovic is a practicing psychiatrist and researcher at the University of Illinois at Chicago whose research focuses on refugees' mental health, PTSD, and social psychiatry.

Andrew Stone is the Director of the Post-Traumatic Stress Disorder Clinical Team at VA Medical Center Philadelphia. His expertise is in mental health, psychotherapy, and PTSD.

John Beahrs professional focus is on consciousness, volition, hypnosis, evolutionary biology, psych \& law, social systems and social causation.

Stephen Shanfield's interests include psychological elements of international relations, conceptual elements of diagnosis, and history of psychiatry.

The authors are members of the Committee on Terrorism and Political Violence of the Group for the Advancement of Psychiatry.

\section{References}

Abdullah X. "Abdullah X: 5 Aspekte zum Nachdenken für Muslime in Bezug auf Syrien (Five Considerations for a Muslim on Syria)." Online Video. YouTube, 8 Mar. 2014. https://www.youtube.com/ watch? $\mathrm{v}=1$ PeqsxyvtZs.

Ahmed, Sameera, and Maha Ezzeddine. 2009. “Challenges and Opportunities Facing American Muslim Youth." Journal of Muslim Mental Health, 4(2): 159-174.

Al-Awlaqi, Anwar. 2008. "Voting for the American President (Part 1)," Web blog post, Imam Anwar AlAwlaqi, October 31 Web. 29, Apr. 2015. http://anwar-awlaki.blogspot.com/2011/10/voting-for-americanpresident-prt-1.html.

Al-Awlaqi, Anwar. 2008. "Voting for the American President (Part 2)," Web blog post, Imam Anwar AlAwlaqi, November 3. Web. 29, Apr. 2015. http://anwar-awlaki.blogspot.com/2011/10/voting-for-americanpresident-prt-2.html.

Al-Awlaki, Anwar. 2010. "Message to the American People," Internet Archive, http://archive.org/details/ AwlakiToUsa.

Braddock, Kurt. "Fighting Words: The Persuasive Effect of Online Extremist Narratives on the Radicalization Process." Ph. D. Dissertation. University of Pennsylvania. 2012. Print.

Braddock, Kurt. 2015. "The Utility of Narratives for Promoting Radicalization: The Case of the Animal Liberation Front.” Dynamics of Asymmetric Conflict, 8: 38-59.

Braddock, Kurt and John Horgan. 2015. “Towards a Guide for Constructing and Disseminating Counternarratives to Reduce Support for Terrorism." Studies in Conflict and Terrorism, DOI: 10.1080/1057610X.2015.1116277.

Braddock, Kurt, and James P. Dillard. "Meta-Analytic Evidence for the Persuasive Effect of Narratives on 
Beliefs, Attitudes, Intentions, and Behaviors." Communications Monographs, forthcoming. Quoted in

Braddock, Kurt and John Horgan. 2015. “Towards a Guide for Constructing and Disseminating Counternarratives to Reduce Support for Terrorism." Studies in Conflict and Terrorism, DOI: 10.1080/1057610X.2015.1116277.

Bartlett, Jamie, Jonathan Birdwell, and Michael King. 2010. The Edge of Violence: A Radical Approach to Extremism. London, UK: Demos.

Beutel, Alejandro J. "Securing the Homeland Against Domestic Al-Qai'da-Inspired Violent Extremism: Partnership Based Approaches with American Muslim Communities?” MA Capstone. University of Maryland, College Park. 2013. Print.

Berger, J.M., and Bill Strathearn. 2013. Who Matters Online: Measuring Influence, Evaluating Content, and Countering Violent Extremism in Online Networks. London, UK: King's College, International Centre for the Study of Radicalisation and Political Violence. http://icsr.info/wp-content/uploads/2013/03/ICSR Bergerand-Strathearn.pdf.

Bhulai, Rafia Barakat, Naureen Chowdhury Fink, and Sara Zeiger. 2014. The Role of Families and Communities in Strengthening Community Resilience Against Violent Extremism. New York, NY: Global Center on Cooperative Security. http://www.globalcenter.org/wp-content/uploads/2013/12/MeetingNote FamiliesandCommunities FINAL May2014.pdf.

Blair, J. Pete, and Katherine W. Schweit. A Study of Active Shooter Incidents in the United States Between 2000 and 2013. Washington, DC: Federal Bureau of Investigation. http://www.fbi.gov/news/stories/2014/ september/fbi-releases-study-on-active-shooter-incidents/pdfs/a-study-of-active-shooter-incidents-in-theu.s.-between-2000-and-2013.

Brachman, Jarret, and Will McCants. 2006. Stealing Al-Qa'ida's Playbook. West Point, NY: United States Military Academy at West Point, Combating Terrorism Center at West Point.

Braniff, William. 2015. "Narratives and Counter-Narratives Pairing Matrix Knowledge Tool for CVE Practitioners and Communities." National Consortium for the Study of Terrorism and Responses to Terrorism at the University of Maryland College Park.

Briggs, Rachel, and Sebastien Feve. 2013. Review of Programs to Counter Narratives of Violent Extremism: What Works and What are the Implications for Government? London, UK: Institute for Strategic Dialogue. http://www.strategicdialogue.org/CounterNarrativesFN2011.pdf.

Council on America Islamic Relations. 2014. "L.A. Based Organizations' Statement on Federal Government's CVE Programs." https://ca.cair.com/losangeles/2014/11/1-a-based-organizations-statement-on-federalgovernments-countering-violent-extremism-programs/

Dafnos, Andrea. 2014. "Narratives as a Means of Countering the Radical Right; Looking into the Trojan T-Shirt Project.” Journal EXIT-Deutschland, 3: 156-188.

Das, Enny, Brad Bushman, Marieke D. Bezemer, Peter Kerkof, and Ivar Vermeulen. 2009. "How Terrorism News Reports Increase Prejudice Against Outgroups: A Terror Management Account.” 45: 453-459.

Fernandez, Alberto M. “Center for Strategic and Counterterrorism Presentation.” University of Maryland, College Park. Headquarters of the National Consortium for the Study of Terrorism and Responses to Terrorism (START). College Park, MD. October 2014. 


\section{Journal of Terrorism Research}

Fernandez, Alberto M. “Confronting the Changing Face of al-Qaeda Propaganda." Washington Institute for Near East Policy. Washington, DC. http://www.washingtoninstitute.org/policy-analysis/view/confrontingthe-changing-face-of-al-qaeda-propaganda. February 25, 2014.

Fink, Naureen Chowdhury, and Bejamin Sugg. 2015. "A Tale of Two Jihads: Comparing the al-Qaeda and ISIS Narratives.” IPI Global Observatory, February 9. http://theglobalobservatory.org/2015/02/jihad-al-qaedaisis-counternarrative/.

Furlow, R. Bennet. 2012. Extremism and Victimhood in the U.S. Context. Tempe, AZ: Arizona State University, Center for Strategic Communication. http://csc.asu.edu/wp-content/uploads/pdf/csc1204-extremismvictimhood-us.pdf.

Ramsay, Gilbert. 2012. “Online Arguments Against Al-Qaeda: An Exploratory Analysis.” Perspectives on Terrorism, 6(1): 54-69.

Glavin, Nicholas, 2015. “Counter ISIS' Narratives on Social Media." The New York Times, The Opinion Pages, December 7.

Goodall Jr., H.L., Pauline Hope Cheong, Kristin Fleischer, and Steven R. Corman. 2012. "Rhetorical Charm: The Promise and Pitfalls of Humor and Ridicule as Strategies to Counter Extremist Narratives." Perspectives on Terrorism, 6(1): 70-79.

Grant, Mark Lyall. "Countering violent extremism is one of the most pressing international challenges that we face," UN at the Security Council Open Debate on Maintenance of International Peace and Security. United Nations Security Council, New York, NY. 23, Dec. 2015.

Halverson, Jeffry R., H. L. Goodall, and Steven Corman. 2011. Master Narratives of Islamist Extremism. New York, NY: Palgrave-MacMillian.

Hedayah and International Centre for Counter-Terrorism - The Hague. 2014. Developing Effective CounterNarrative Frameworks for Countering Violent Extremism. http://www.icct.nl/download/file/Developing\%20 Effective\%20CN\%20Frameworks Hedayah ICCT Report FINAL.pdf.

Holmer, Georgia. 2014. Creating Spaces for Effective CVE Approaches. Washington, D.C.: United States Institute for Peace.

Hudson, Laura. 2014. "First Look at the New Ms. Marvel, A 16-Year-Old Muslim Superhero." Wired, 7 Jan. http://www.wired.com/2014/01/ms-marvel-muslim-superheroine/\#slideid-540391.

Infante, D.A., et al. 1992. "Initiating and Reciprocating Verbal Aggression: Effects on Credibility and Credited Valid Arguments." Communication Studies, 43(3): 182-190;

Infante, D.A., and C.J. Wigley. 1986. "Verbal Aggressiveness: An Interpersonal Model and Measure." Communication Quarterly, 53(1): 61-69.

Jacobsen, Michael. 2010. "Learning Counter-Narrative Lessons from Cases of Terrorist Dropouts." In, Countering Violent Extremist Narratives. Ed. Eelco J.A.M. Kessels. The Hague, Netherlands: National Coordinator for Counterterrorism.

Matejic, Nicole. "Why We Don't Need a CVE “counter Narrative": This War Is about Actions, Not Words." Web log post. Nicole Matejic. Info Ops HQ, 12 Dec. 2015. Web. 10 Jan. 2016. <http://www.nicolematejic.com/ info-ops/why-we-dont-need-a-cve-counter-narrative-this-war-is-about-actions-not-words/ $>$.

Khan, Mussarat, and Kathryn Ecklund. 2012. “Attitudes Toward Muslim Americans Post-9/11." Journal of 


\section{Journal of Terrorism Research}

Muslim Mental Health, 7(1), http://hdl.handle.net/2027/spo.10381607.0007.101.

Khan, Samir. 2011. “Blended Duality: Muslim and American?," Inspire Magazine, 8, http://azelin.files. wordpress.com/2012/05/inspire-magazine-8.pdf.

Kruglanski, Arie W. 2014. "Psychology, Not Theology: Overcoming ISIS' Secret Appeal." E-International Relations, October 28. http://www.e-ir.info/2014/10/28/psychology-not-theology-overcoming-isis-secretappeal/.

Kundnani, Arun. 2012. Blind Spot? Security Narratives and Far-Right Violence in Europe. The Hague, Netherlands: International Centre for Counter-Terrorism. http://www.icct.nl/download/file/ICCTKundnani-Blind-Spot-June-2012.pdf;

LaFree, Gary, and Bianca Bersani. 2012. Hot Spots of Terrorism and Other Crimes in the United States, 1970-2008. College Park, MD: National Consortium for the Study of Terrorism and Responses to

Terrorism. http://www.start.umd.edu/sites/default/files/files/publications/research briefs/LaFree Bersani HotSpotsOfUSTerrorism.pdf.

Liht, Jose, and Sara Savage. 2013. "Preventing Violent Extremism Through Value Complexity: Being Muslim Being British." Journal of Strategic Security, 6(4): 44-66.

McCants, William, and Clinton Watts. 2012. U.S. Strategy for Countering Violent Extremism. Philadelphia, PA: Foreign Policy Research Institute. http://www.fpri.org/docs/media/McCants Watts - Countering Violent Extremism.pdf.

Merica, Dan. 2011. "Muslim Superhero Comics Meet Resistance in U.S." Web blog post. Belief Blog, CNN, 5 Oct. http://religion.blogs.cnn.com/2011/10/05/muslim-superhero-comic-series-meets-resistance-in-u-s/. Moscovici, S., and M. Zavalloni. 1969. “The Group as a Polarizer of Attitudes.” Journal of Personality and Social Psychology, 12(2): 125-135.

Muslim Public Affairs Council. "Injustice Cannot Defeat Injustice." Online Video. YouTube, 12 Jul. 2010. https://www.youtube.com/watch?v=3IofpsHOosE.

Nasser-Eddine, Minerva, et al. 2011. Countering Violent Extremism (CVE) Literature Review. Edinburgh, Australia: Australian Government Department of Defence, Defence Science and Technology Organization. http://dspace.dsto.defence.gov.au/dspace/bitstream/1947/10150/1/DSTO-TR-2522\%20PR.pdf

National Counterterrorism Center. 2012. Annex of Statistical Information, McLean, VA: National

Counterterrorism Center. http://www.state.gov/documents/organization/195768.pdf

Neumann, Peter R. 2014. The New Jihadism: A Global Snapshot. London, UK: International Centre for the Study of Radicalisation and Political Violence. http://icsr.info/wp-content/uploads/2014/12/ICSR-REPORTThe-New-Jihadism-A-Global-Snapshot.pdf

No author. Jihad and the Islamic Law of War. Amman, Jordan: The Royal Aal-al Bayt Institute for Islamic Thought, 2009.

No Hate USA. 2015. "About Us". National Outreach for Hate Awareness and Threat Education USA, n.d., Web. 29 Apr. http://www.nohateusa.org/about-us.html.

Perliger, Arie. 2012. Challengers from the Sidelines: Understanding America's Violent Far-Right. West Point, NY: United States Military Academy at West Point, Combating Terrorism Center. https://www.ctc.usma.edu/ wp-content/uploads/2013/01/ChallengersFromtheSidelines.pdf 


\section{Journal of Terrorism Research}

Peters, Gjalt-Jorn Ygram, Robert A.C. Ruiter, and Gerjo Kok. 2013. “Threatening Communication: A Critical Re-Analysis and a Revised Meta-Analytic Test of Fear Appeal Theory." Health Psychology Review, Supplement 1: S8-S31. DOI: 10.1080/17437199.2012.703527

Petrosino, Anthony, Carolyn Turpin Petrosino, John Buehler. 2004. Scared Straight' and other Juvenile Awareness Programs for Preventing Juvenile Delinquency. Oslo, Norway: The Campbell Collaboration. http:// www.campbellcollaboration.org/lib/download/13/Scared+Straight R.pdf

Piazza, James A. 2009. "Is Islamist Terrorism More Dangerous?: An Empirical Study of Group Ideology, Organization, and Goal Structure." Terrorism and Political Violence, 21(1): 62-88.

Prevention First. 2008. Ineffectiveness of Fear Appeals in Youth Alcohol, Tobacco, and Other Drug (ATOD) Prevention. Springfield, IL: Prevention First.

Quraishi-Landes, Asifa. 2011. Sharia and Diversity: Why Some Americans are Missing the Point. Washington, D.C: Institute for Social Policy and Understanding. http://www.ispu.org/pdfs/ISPU_Report_ShariaDiversity_ Final_web.pdf

Rascoff, Samuel. 2012. "Establishing Official Islam? The Law and Strategy of Counter-Radicalization.” Stanford Law Review, 64: 125-190.

Ruston, Scott W. 2009. "Understanding What Narrative is and Does." Arizona State University Center for Strategic Communication, September 3. http://csc.asu.edu/2009/09/03/understand-what-narrative-is-anddoes/.

Sageman, Marc. 2004. Understanding Terror Networks. Philadelphia, PA: University of Pennsylvania Press. Savage, Sara. 2011. "Four Lessons from the Study of Fundamentalism and Psychology of Religion." Journal of Strategic Security, 4(4): 131-150.

Savage, Sara, J. Liht, and R. J. Williams. 2011. "Being Muslim Being British: Preventing Extremist Violence Through Raising Integrative Complexity." Eds. M. Sharpe and F.Gere. The Intangibles of Security. Amsterdam, Netherlands: IOS Press, 2011.

Schmid, Alex P. 2014. Al-Qaeda's 'Single Narrative' and Attempts to Develop Counter-Narratives: The State of Knowledge. The Hague, Netherlands: International Center for Counter-Terrorism. http://www.icct.nl/ download/file/AP-Schmid-Al-Qaedas-Single-Narrative-January-2014.pdf.

Semic, B.A. and D.J. Canary. 1997. “Trait Argumentativeness, Verbal Aggressiveness and Minimally Rational Argument." Communication Quarterly, 45(4): 355-378.

Sides, John, and Kimberley Gross. 2013. "Stereotypes of Muslims and Support for the War on Terror." The Journal of Politics, 75(3): 583-598

Smith, Allison, Peter Suedfeld, Lucian G. Conway III, and David G. Winter. 2008. “The Language of Violence: Distinguishing Terrorist from Nonterrorist groups by Thematic Content Analysis." Dynamics of Asymmetric Conflict: Pathways Toward Terrorism and Genocide, 1(2): 142-163.

Stern, Jessica, and J.M. Berger. 2014. ISIS: The State of Terror. New York, NY: Ecco Books.

Strange, Hannah. 2014. "Iraq crisis: Top Shia cleric Sistani withdraws support for PM Maliki - live." The Telegraph, 20 Jun. http://www.telegraph.co.uk/news/worldnews/middleeast/iraq/10913727/Iraq-crisisObama-dispatches-300-US-military-advisers-live.html.

Al-Tamimi, Aymenn Jawad. 2014. “ISIS, al-Qaeda Compete for Supremacy in Global Jihad." Al Monitor, 


\section{Journal of Terrorism Research}

February 11. http://www.al-monitor.com/pulse/ar/originals/2014/02/isis-qaeda-zawahri-baghdadi-jihadistsyria-iraq.html\#.

Truitt, Brian. 2011. “'The 99’ Aspires to Teach Muslim Principles.” USA Today, 19 Sep. http://usatoday30. usatoday.com/life/comics/story/2011-09-19/the-99-muslim-inspired-superheroes/50471634/1.

Tuck, Henry and Tanya Silverman. 2016. The Counter-Narrative Handbook. London, UK: Institute for Strategic Dialogue. http://www.strategicdialogue.org/wp-content/uploads/2016/06/Counter-narrativeHandbook 1.pdf

United States Department of Homeland Security. 2008. Terminology to Define the Terrorists:

Recommendations from American Muslims. Washington, DC: U.S. Department of Homeland Security, Office of Civil Rights and Civil Liberties. http://www.dhs.gov/xlibrary/assets/dhs crcl terminology 08-1-08 accessible.pdf

United States. Cong. House. Committee on Homeland Security. Hearing on Worldwide Threats to the Homeland, United States House, 113th Cong. 2nd sess. Washington, DC: Government Printing Office, 2014. (statement of Jeh Johnson, Secretary, U.S. Department of Homeland Security).

United States. Cong. House. Committee on Homeland Security. Hearing on Worldwide Threats to the Homeland, United States House, 113th Cong. 2nd sess. Washington, DC: Government Printing Office, 2014. (statement of James E. Comey, Director, Federal Bureau of Investigation).

Wagemakers, Joas. “'The Kafir Religion of the West': Takfir of Democracy and Democrats by Radical Islamists," in Accusations of Unbelief in Islam. A Diachronic Perspective on Takfir, edited by Camilla Adang, Hassan Ansari, Maribel Fierro, and Sabine Schmidke, 327-353. Boston: Brill Publishers, 2016.

Watts, Clinton. "Are We Our Own Worst Enemy? The Problems in Countering Jihadi Narratives and How to Fix Them.” Web blog post. Geopoliticus. Foreign Policy Research Institute, 2 May 2015. Web. 4 Jun. 2015. 